\title{
Go hand in hand: Showcasing lecturers' online collaborative teaching practices
}

\author{
Elis Homsini Maolida* and Anisa Sofarini \\ English Education Study Program, Faculty of Education and Teacher Training, Universitas Suryakancana \\ Jl. Pasirgede Raya, Bojongherang, Kec. Cianjur, Kabupaten Cianjur, Jawa Barat 43216
}

\begin{tabular}{|c|c|}
\hline $\begin{array}{l}\text { ABSTRACT } \\
\text { Collaborative teaching has been performed by special } \\
\text { and myriads of studies have witnessed its promising in } \\
\text { Notwithstanding its vogue, only a few studies have prir } \\
\text { higher education. Furthermore, empirical attempts acc } \\
\text { during collaborative teaching implementation remain } \\
\text { practices are undertaken online. This study, henceforth } \\
\text { experiences of two collaborating lecturers, leading Te } \\
\text { (TEFL) and Technology-Enhanced Language Learning } \\
\text { practices were documented for } 20 \text { weeks and their views } \\
\text { perceived their online co-teaching practices. In additi } \\
\text { students were assembled at the end of the term through fo } \\
\text { Practice Development (JPD) framework, lecturers' onlin } \\
\text { captured and conceptually grouped into five develo } \\
\text { collaborative instruction, peer feedback and evaluatic } \\
\text { Admitting lecturers online co-teaching approach, stude } \\
\text { was opportune in bridging their needs of pedagogica } \\
\text { facilitating learning efficiency, and fostering their } \\
\text { effectiveness, students are also concerned with colla } \\
\text { proficiency, and autonomy. Thus far, this teaching ap } \\
\text { higher education, with clear format to adopt. }\end{array}$ & $\begin{array}{l}\text { ors in K-12 schools for decades, } \\
\text { on both students and teachers. } \\
\text { dealt with its implementation in } \\
\text { ing lecturers' stepwise practices } \\
\text {-explored, especially when the } \\
\text { as to fill the void. In total, the } \\
\text { English for Foreign Language } \\
\text { course, were scrutinized. Their } \\
\text { also assembled to grasp how they } \\
\text { views from six representative } \\
\text { group discussion. Through Joint } \\
\text { borative teaching practices were } \\
\text { tages - collaborative planning, } \\
\text { llow up, and refinement stage. } \\
\text { ontended that its implementation } \\
\text { wledge and related technology, } \\
\text { boration awareness. Albeit its } \\
\text { on appearance clarity, learning } \\
\text { is worthy of continuing in the }\end{array}$ \\
\hline \multicolumn{2}{|c|}{ Keywords: Joint practice development (JPD); online collaborative teaching; TEFL; TELL } \\
\hline $\begin{array}{cc}\text { First Received: } & \text { Revised: } \\
\text { 1 September } 2021 & \text { 5 January } 2022 \\
\text { Final Proof Received: } & \\
\text { 27 January 2022 } & \\
\end{array}$ & $\begin{array}{c}\text { Accepted: } \\
\text { 20 January 2022 } \\
\text { Published: } \\
\text { 31 January 2022 } \\
\end{array}$ \\
\hline $\begin{array}{l}\text { How to cite (in APA style): } \\
\text { Maolida, H. E. \& Sofarini, A. (2022). Go hand in hand } \\
\quad \text { collaborative teaching practices. Indonesian Jourr }\end{array}$ & $\begin{array}{l}\text { asing lecturers' online } \\
\text { pplied Linguistics, } 11(3), 553 \text { - }\end{array}$ \\
\hline
\end{tabular}

\section{INTRODUCTION}

Higher education (HE) worldwide is undergoing numerous transformations. These changes demand immediate adjustments (Eriksson et al., 2020), particularly in teaching and learning process. Technology expansion (see Kennedy et al., 2016; Marcelo \& Yot-Domínguez, 2019), and the aftermath of Covid-19 emergency for the past two years (see Mishra et al., 2020; Toquero, 2020), are the key drivers of the teaching transition in HE. From classroom to Zoom, personal to virtual are just some of the types (Mishra et al., 2020). To this point, online teaching comes to the forefront as a sole viable choice to meet the demand. This pedagogical change in $\mathrm{HE}$ is a critical period for lecturers to rethink, revamp, and redesign their existing teaching practices. Therefore, it is assumed that forming a teaching dyad could be a potential support for lecturers to design an effective online teaching and mingle with current online technologies. As claimed by Scribner-MacLean and Miller (2011), teaching online collaboratively is

\footnotetext{
* Corresponding Author

Email: anisa.sofarini@unsur.ac.id
} 
more advantageous compared to teaching online solo.

Collaborative teaching, also known as coteaching, is one of the key facets of teacher collaboration (Eriksson et al., 2020), and is defined variously. Pratt et al. (2017), for instance, defined it as a partnership between general and special educators to teach students with disabilities. To clarify how this study understands co-teaching, the practicality and environment are two distinctive features at hand. The definition from Eriksson et al. (2020) shows the practicality of co-teaching. They specifically described it as two or more educators collaborating to share instructional tasks, i.e. teaching plan, arrangement, delivery, and assessment (Eriksson et al., 2020). Merging this practical definition to Scribner-MacLean and Miller's (2011) notion of 'single learning environment', so-called online space, has supported this study to justify that online collaborative teaching notion is acceptable. In light of those preceding definitions, this study views collaborative teaching as two or more lecturers working as a teaching dyad to jointly share values in designing online teaching, arranging online meeting, delivering learning materials online, and conducting online assessment.

\section{Online Collaborative Teaching in $\mathbf{H E}$}

Collaborative teaching has been performed by special educators in K-12 schools for decades since the inclusive schooling was historically embraced in the 1980s (Friend et al., 2010). Myriads of studies have proven the edge of collaborative teaching in K12 schools (Morelock et al., 2017; ScribnerMacLean \& Miller, 2011). However, adopting online co-teaching in $\mathrm{HE}$ is still relatively novel. This may be due to collaborating in research remains popular among university professionals, not necessarily collaborating in teaching (Lock et al., 2017). The knowledge about collaborative teaching in the online spaces also remains scarce (Eriksson et al., 2020). In light of its well-found impacts on K-12 schools, university professionals may take coteaching strategy into account. They may admit it as a new way of working at the university (Kluth \& Straut, 2003; Woźniak, 2013). Since collaborative teaching approach is also crucial at the university (Woźniak, 2013), lecturers will have a chance to merge their expertise to assist the learning process (Gillespie \& Israetel, 2008) and elevate teaching performance as well as upgrade teaching quality (González \& Skultety, 2018). A common syllabus is developed by collaborating instructors, whose integrated perspectives and teaching contents as well as activities are jointly selected (Letterman \& Dugan, 2004). As with face-to-face instructors, online instructors are responsible for creating a positive and productive classroom environment in much the same way.
Diverse co-teaching models can be incorporated into online teaching in HE. They range from models where instructors jointly plan the course but have limited interaction in the online course to models where course material and pedagogy are fully intertwined and each instructor is accountable for the whole course contents (Shapiro $\&$ Dempsey, 2008). More specifically, Bacharach et al. (2008) and Cook and Friend (1995) categorized collaborative teaching strategies based on the instructors' roles and duties. One teach one observe strategy obliges one instructor to take the lead in the majority of teaching responsibilities while the other is observing certain behaviors. In the same vein, one teach one drift strategy allows one instructor does the teaching and the other help students with their task, observe behavior, or assess students' assignments. The instructional content is separated into portions in the station teaching strategy, and each teacher teaches one group of pupils, who then rotates from one teacher to the next. The pupils are separated into groups in the parallel teaching strategy, and each teacher teaches one group with similar instructional material. A supplemental teaching strategy implies that one teacher works with pupils at their expected skill level while another concentrates on individuals who require additional or remedial instruction. The alternative or differentiated teaching strategy suggests that teachers use a variety of ways to achieve common learning purposes, but the team teaching strategy implies that all teachers are actively engaged in teaching at the same time with no prescribed authority division. Two or more teachers can offer sessions in a team teaching style by taking shifts (Dugan \& Letterman, 2008). Also known as tag rotation or theme-based co-teaching strategy, team teaching strategy allows teachers to align content with their expertise and knowledge base (Money \& Coughlan, 2016). Instructors in theme-based coteaching teach at the same level on the same topic or various levels on other topics or even disciplines.

Online co-teaching offers merits for the instructors (Eriksson et al., 2020). One of the most essential ones is that teaching alongside a peer can provide co-instructors with the opportunity to engage more deeply in philosophical conversations concerning course contents (Hulbert \& McBride, 2004; Letterman \& Dugan, 2004). Through this, experts from diverse content areas can share academic resources and learn from one another. As much as online co-teaching has its merits, it also has challenges. Different teaching style is a major anticipated issue (Shapiro \& Dempsey, 2008). To anticipate this, instructors should conduct an intensive discussion. The discussion should mainly direct which strategy makes the most sense for the information being introduced prior to the start of the class (Scribner-MacLean \& Miller, 2011). Despite its merits and challenges, it should be obvious from 
the beginning which of the previously outlined coteaching methodologies is the most appropriate to adopt.

\section{Joint Practice Development (JPD)}

Collaborative teaching and Joint Practice Development (JPD) are complementary concepts in nature. When instructors work together, JPD places a high value on how they interact and learn from one another to improve the quality of their practices. Therefore, JPD framework allows this study to picture how collaborating lecturers are working closely and supporting one another to improve their online teaching practices. Firstly proposed by Fielding et al. (2005), the term 'JPD' is defined as "the existing practice of teachers who are trying to learn new ways of working, and acknowledges the effort of those who are trying to support them, both in their having developed creative ways of working and the complex task of opening up and sharing practices with others" (p. 32). JPD encapsulates a highly collaborative, not one-way process in which the technique is refined rather than just transferred from one person to another (National College for School Leadership, 2012). More importantly, JPD differs from typical professional learning approaches in that it encourages instructors to collaborate over time in a trusting and democratic atmosphere in order to share what they have learned not what they know (Herbert-Smith, 2017). Various JPD models have been evolving since the report was made by Michael Fielding and colleagues in 2005 (see CUREE, 2018; Fielder \& Pearce, 2021). There is no standard for modelling JPD since it differs and is designed in response to the various field practices. However, a 'road-map' proposed by Herbert-Smith (2017) can become a guideline to document the practices (see Figure 1).

Figure 1

The work of JPD

How Joint Practice Development works

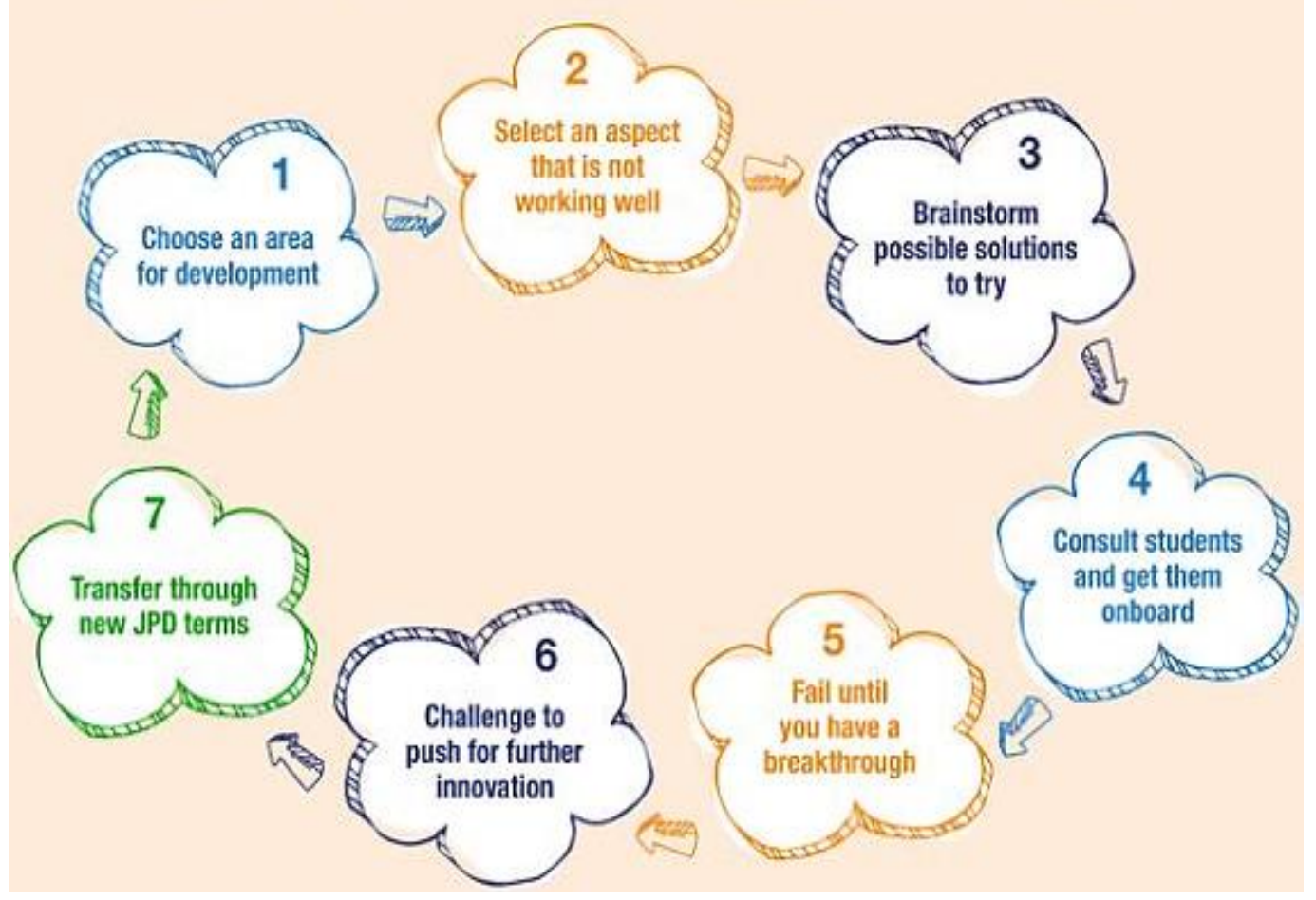

This JPD framework has led this study to catalogue and delineate how lecturers were hand in hand in practicing online teaching. Although research on online collaborative teaching has started to emerge (see Eriksson et al., 2020; Friend \& Barron, 2021; Scribner-MacLean \& Miller, 2011), empirical attempts accentuating the lecturers' stepwise practices during online collaborative teaching remain under-explored. Henceforth, this study intends to fill the void. This study attempts to capture and document how lecturers perform online teaching and delineate how they learn from one another to elevate their teaching skill. Furthermore, since students' involvement is equally crucial in JPD framework (Herbert-Smith, 2017), this study also attempts to document students' standpoints as a response to their lecturers' online co-teaching effort.

\section{METHOD}

Lecturers' phased practices during online collaborative teaching implementation and students' 
standpoints are the cores of this study. To grasp lecturers' practices and students' viewpoints, the empirical part of the study was undertaken using descriptive qualitative research method. By adopting qualitative research, this study has carried out an indepth investigation and generated detailed, rich data according to the participants' experiences, perspectives, and histories (Bhattacharya, 2017; Braun \& Clarke, 2013). In this regard, this study drew heavily on the participants' experiences by examining their step-by-step practices during online co-teaching, from jointly planning to evaluating their online instruction. Acknowledging the fact that deconstructing assumptions is one of the qualitative research purposes (Bhattacharya, 2017), this study attempts to break apart students' perceptions of how their lecturers' online collaborative teaching effort benefits and hinders their online learning experiences.

\section{Participants}

Two lecturers and three classes of TEFL-TELL students took part in this study. Participants were involved through purposive sampling on the basis of participants' characteristics or experiences correlated to the researcher topic (Matthews \& Ross, 2010). With this in mind, lecturers who participated in this study had experience in online co-teaching. The lecturers are from English Education Department and collaborated to teach integrated courses at the same level. Lecturer 1 (L1) - taught Teaching English for Foreign Language (TEFL) course, while lecturer 2 (L2) taught TechnologyEnhanced Language Learning (TELL) course. In addition, six third-year students (S1-S6) taking both TEFL and TELL courses were also involved to represent the students' voices on the merits and challenges of the online collaborative teaching practices.

\section{Data Collection}

The data were gathered through observation, semistructured interviews, and students' focus group discussions (FGD). The observation (Creswell, 2003) was carried out to gain the data about the lecturers' phased practices. Regarding the time and setting of the observation (Bhattacharya, 2017), this study took place in an online classroom setting for 20 weeks due to the Covid-19 outbreak. Lecturers began to collaborate in planning for 2 weeks, teaching for 16 weeks (with more emphasis on asynchronous mode of learning in Week 9 to Week 15), and conducting assessment for the following weeks. Semi-structured interview (Rabionet, 2011) was then undertaken to grasp lecturers' reflections regarding their collaboration. Meanwhile, the FGD (Dilshad \& Latif, 2013) was carried out to assemble students' standpoints. In this case, the FGD was conducted via a conferencing platform for about 1.5 hours.

\section{Data Analysis}

Under the umbrella of Joint Practice Development (JPD) framework (Herbert-Smith, 2017), the data from observation and the lecturers' semi-structured interviews were integrated and categorized to bore several themes of stages of online co-teaching process. The interview was also transcribed and analyzed to discuss the lecturers' reflections on their co-teaching practices to inform the observation results. Furthermore, the FGD recording result was also transcribed, grouped, and categorized into several themes of the students' perspectives on the benefits and challenges of online co-teaching practices. These findings from three data sources were interpreted and discussed to elaborate an ample description of the TEFL-TELL online collaborative teaching practices as well as its merits and challenges.

\section{FINDINGS \& DISCUSSION}

\section{Lecturers' Online Collaborative Teaching Practices}

As depicted in the following circular flowchart (see Figure 2), lecturers engaged in a number of activities when working in tandem to carry out online teaching. Their co-teaching ran for 20 weeks. These lecturers' iterative activities were attained from asynchronous online classroom observations and semi-structured interviews. As JPD allows for the development of practices based on the goal of collaboration, the practices of co-lecturers catalogued in this study were formed based on what actually occurred during their online co-teaching.

Lecturers decided to become a teaching dyad since the topic coverage of the TEFL and TELL courses are knowingly complementary. The TEFL course primarily covers English teaching methodologies. Then, various educational technology tools explored in the TELL course complement English teaching methodologies as the instructional media. Co-lecturers worked together from planning the online course to the end of the term. What they did represented the collaborative teaching nature. In intertwining collaborative teaching, collaborating instructors are hand in hand in planning, arranging, conducting teaching and learning, and assessing students' attainment (Eriksson et al., 2020).

\section{Collaborative Planning}

As part of their online co-teaching, lecturers began by planning. As collaborative planning is an essential aspect to success (Pratt et al., 2017), lecturers started planning one month prior to the new term in September 2020. Lecturers collaboratively planned course syllabus, online instruction format, and course assessments. In response to this, $\mathrm{L} 1$ in the interview session 
witnessed to how vital planning is as this was their first time collaborating and dealing with online teaching. To this point, L2 added that during the entire planning phase active talks in relatively friendly environments were formed and maintained.

\section{Figure 2}

\section{The JPD Model of Lecturers' Online Collaborative Teaching}

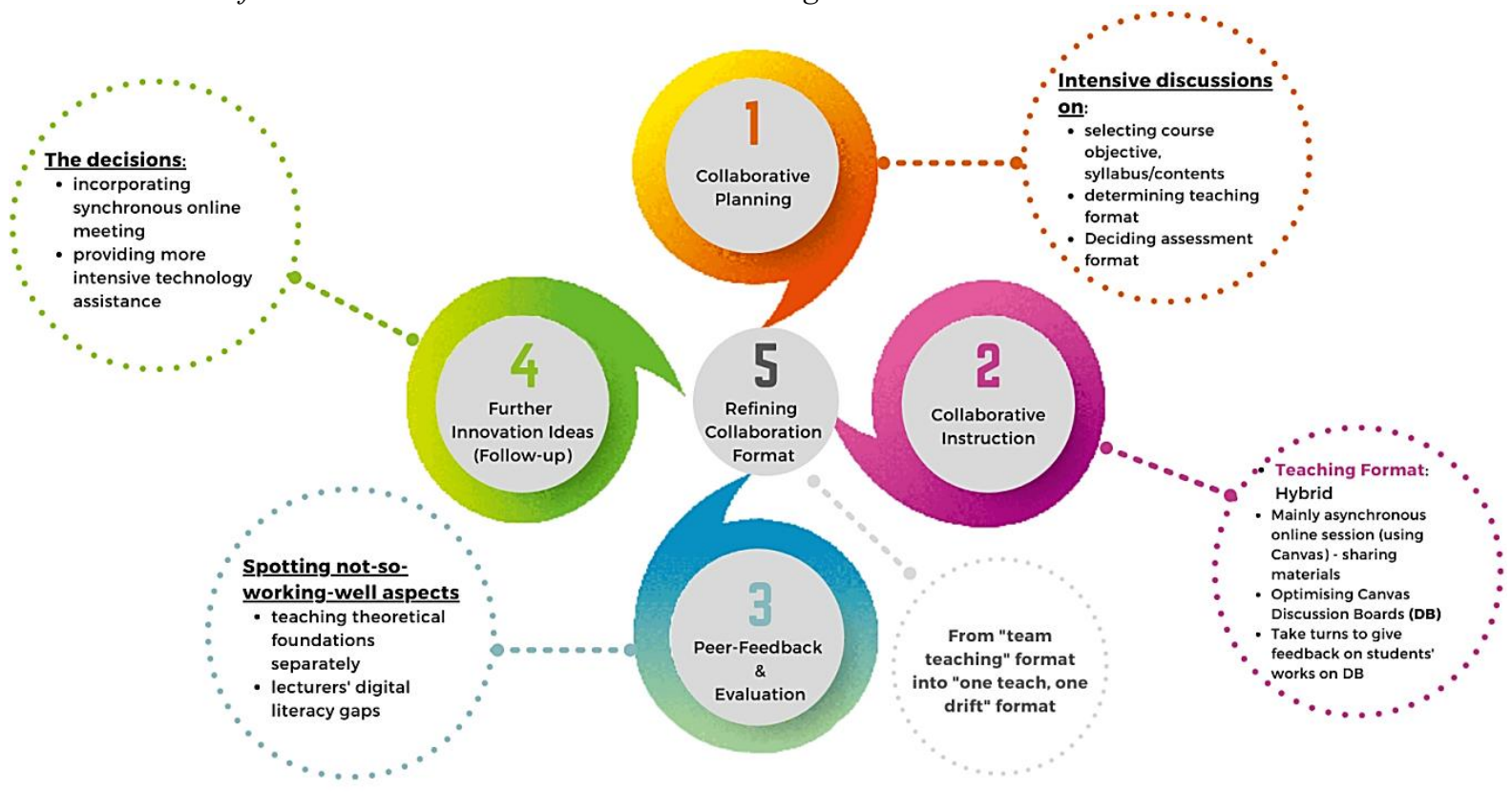

Lecturers found composing course syllabus formidable when it came to selecting which contents from each course that could be merged. They had to ensure the selected topics would complement one another. In this instance, both instructors should pool their knowledge to establish a consensus on how teaching and learning will take place (Sileo, 2011; Tannock, 2009). They discussed and figured out that practical topics tended to be more flexible to be integrated, compared to the theoretical ones. In addition, co-lecturers further concerned about whether or not a topic/content can be taught effectively online. Due to the fact that face-to-face learning materials cannot easily be transferred to an online setting (Kebritchi et al., 2017), adjusting existing classroom-based contents and generating new ones for online instruction can be laborious $\mathrm{Li}$ \& Irby (2008). Acknowledging this, lecturers agreed to place the theoretical topics of each course in the second through seventh meetings. Delivering merged topics, on the other hand, would be in the following meetings.

While co-planning, the lecturers perceived that setting aside a specific time to meet was one of the greatest hindrances they faced. Due to the fact that they are geographically dispersed, there was no set planning schedule. They preferred to choose a time that was both flexible and focused. They discussed virtually through a video platform at least two days a week (see L1's excerpt). If they urgently needed to confirm something, they mostly had text-based conversations through messaging apps. What is worth noting from their co-teaching relationship is that the ways they built and maintained regular and friendly communication as a crucial element for coteaching (Scribner-MacLean \& Miller, 2011). Therefore, both of them felt comfortable talking, learning, and exchanging information with each other in designing online teaching. With this in mind, proximity seemingly became one of the contributing factors in maintaining effective communication during co-teaching practices (see L2's excerpt). In line with Hulbert and McBride (2004) and Letterman and Dugan (2004), coteaching can provide co-instructors with the opportunity to engage more deeply in the philosophical conversations concerning course content, just as it is advantageous for students to be exposed to multiple perspectives.

L1: Since working from home, we were struggling with both home and office works. We have lots to do at the same time. I think, both of us sometimes feel overwhelmed by the workloads we have. So, I think having a strict schedule to meet for preparing materials is hard to do. We usually ask each other if we are available to meet online. If both of us say yes, we indeed have meeting. But, we always try to meet virtually via Zoom, or sometimes WhatsApp video call twice a week. But, if it is urgent, we usually send texts via WhatsApp or Telegram.

L2: I felt comfortable to work together with her. She's not judgmental, so that I don't feel burdened to deliver my opinions when we discuss something. I can say I'm psychologically close to her since she has a motherly trait. I like that. I learn a lot from 
her. The way she thoughts, teaches, plans instruction, like literally everything.

With this in mind, the intensive discussion and proximity between co-lecturers have to be taken into account in building an effective co-teaching relationship.

\section{Collaborative Instruction}

Lecturers' online co-teaching practices were manifested in the instruction. In undertaking online teaching, lecturers embraced asynchronous instruction mode to teach students who were learning from home. Lecturers began to teach students together in the following mid-term examination, precisely from the ninth to the fifteenth meeting. Asynchronous online interaction, in contrast to synchronous mode, allows students and instructors to engage at different times and place, and students can access learning materials and tasks at their own convenience via discussion boards, blogs, or e-mail (Lucas, 2018; Shahabadi \&
Uplane, 2015). Co-lecturers in this study utilized a Learning Management System (LMS) to mediate their online teaching. As relying on an LMS for asynchronous learning is essential (Hadullo et al., 2018), Canvas was appointed by the co-lecturers due to its well-built functionalities. L2 argued that Canvas has complete features and is distinctive from any other LMS in a way that it allows unlimited integration into the other resources, such as YouTube or other web-based applications. "These applications can be opened inside Canvas and will not be automatically opened in a new tab," she added.

To facilitate their asynchronous instruction, the lecturers optimized Canvas pages and discussion boards (see Figure 3). Prior to create the discussion forums, each lecturer prepared and discussed learning materials to share. They ensured that the materials from both courses were correlated. L1 was then in charge to put all materials to Canvas pages and published them.

Figure 3

Lecturers' Canvas Pages and List of Discussion Forums Created by the Lecturer

\begin{tabular}{|c|c|c|c|c|c|c|}
\hline BigBlueButton & & $\square$ UNIT 5 - Principles of Teaching and Learning Grammar & \multirow{7}{*}{\multicolumn{2}{|c|}{$\begin{array}{l}\text { Home } \\
\text { Announcements } \\
\text { Syllabus } \\
\underline{\text { Modules }} \\
\text { Discussions } \\
\text { BigBlueButton } \\
\text { Attendance } \\
\underline{\text { Rubrics }} \\
\text { Collaborations } \\
\text { Assignments } \varnothing \\
\text { cilor }\end{array}$}} & \multirow{2}{*}{$\vdots \vdots$} & \multirow{2}{*}{$\begin{array}{l}\text { Week } 4 \text { - Discussion Forum - Class A } \\
1 \text { section } \\
\text { Last post at } 2 \text { Oct } 2020 \text { at } 8: 50\end{array}$} \\
\hline Attendance & & $\square$ UNIT 6 - Techniques to Teach Grammar (3) & & & & \\
\hline $\begin{array}{l}\text { Rubrics } \\
\text { Collaborations }\end{array}$ & & $\square$ UNIT 7-Technology and Teaching and Learning Grammar & & & $\dddot{\vdots}:$ & $\begin{array}{l}\text { Week } 4 \text { - Discussion Forum - Class B } \\
1 \text { section } \\
\text { Last post at } 28 \text { Sep } 2020 \text { at } 18: 09\end{array}$ \\
\hline & $\varnothing$ & $\square$ Week 9 -Sources of Teaching Speaking Techniques & & & & Week 4 - Discussion Forum - Class C \\
\hline $\begin{array}{l}\text { Files } \\
\text { Pages }\end{array}$ & $\varnothing$ & $\square$ Week 2-Educational Technology Footprints & & & $: \vdots$ & $\begin{array}{l}1 \text { section } \\
\text { Last post at } 28 \text { Sep } 2020 \text { at 13:52 }\end{array}$ \\
\hline$\underline{\text { Grades }}$ & $\varnothing$ & $\square$ Week 2-Unit Outline & & & & Week 3-Online Meeting-Class B \\
\hline People & $\varnothing$ & - Week 4 - Bandwidth Immediacy Matrix & & & $::$ & Last post at 24 Sep 2020 at 2:13 \\
\hline
\end{tabular}

Figure 4 presents the discussion tasks created by lecturers and the lecturers' feedback on the students posts. Mainly, the tasks required students to read, think, and build their arguments. Within a week, students were asked to share their thoughts in the forums and to engage in the discussion by leaving comments to their friends' posts. Lecturers then took turn to give feedback by commenting on the students' posts. This was the way lecturers interacted with the students during the online teaching.

In regards to this, in the interview L1 assumed that this kind of learning activity enabled them to create a learning community and let students build the sense of responsibility through providing valuable arguments and responses. In line with Paloff and Pratt's (2010) suggestion, there should a sense of community for collaboration to happen. This way, students will feel connected to the course materials as well as to their instructors (ScribnerMacLean \& Miller, 2011). Furthermore, L2 argued that students would have more time and flexibility to get knowledge from what they shared. She believed that creating a discussion forum is one of the useful alternatives for students' asynchronous online learning.

From this result, online collaborative teaching has led lecturers to create a new room for pedagogical interaction, for instance through asynchronous discussion boards. The fact that both lecturers were responsible for delivering learning materials, their online collaborative teaching obviously represents team teaching strategy. In team teaching strategy, instructors may align content with their expertise and knowledge base without prescribed authority division (Bacharach et al., 2008; Money \& Coughlan, 2016). 


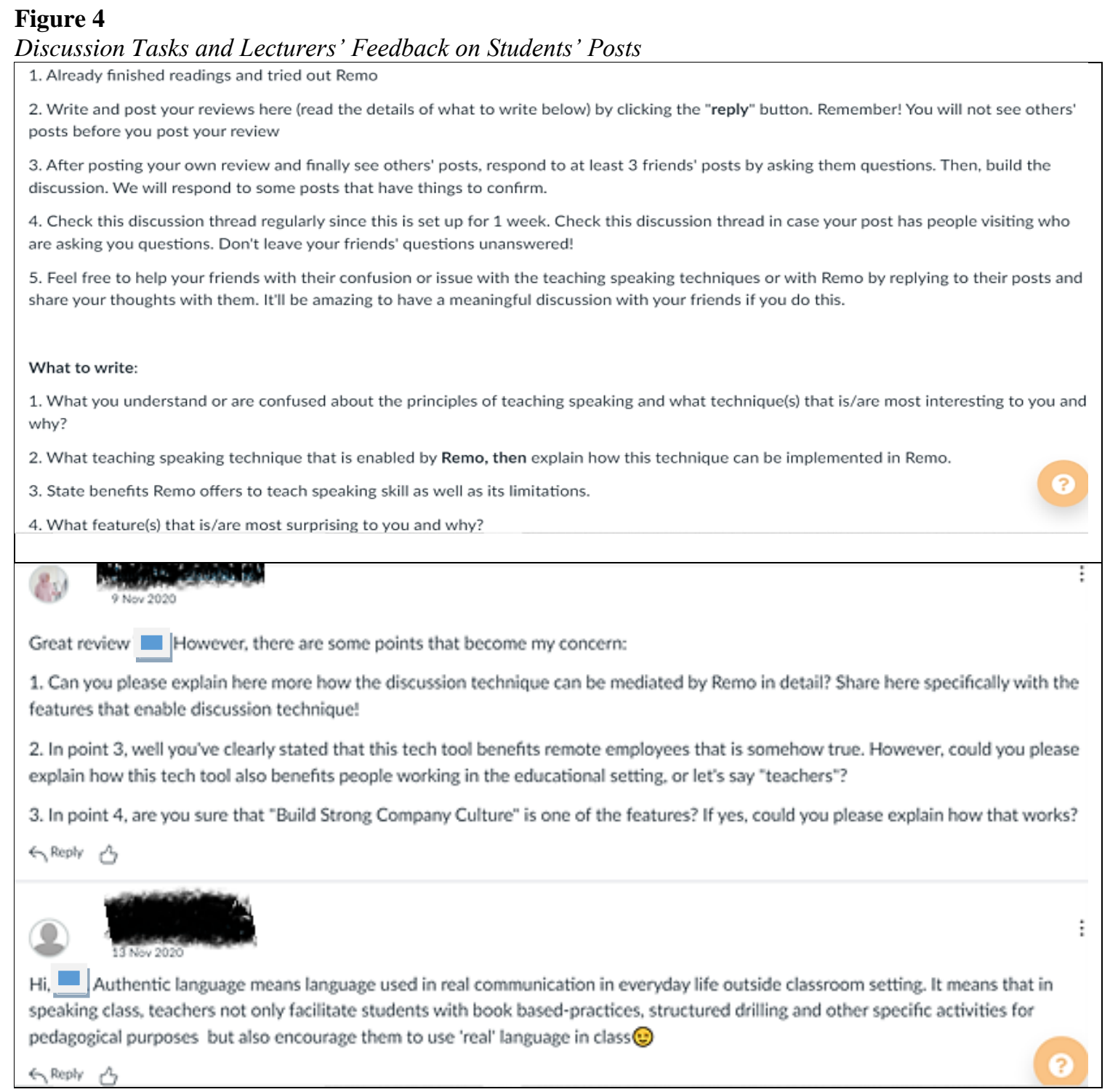

\section{Peer-Feedback and Evaluation}

In the work of JPD, collaborating lecturers should reflect on their collaborative practices and choose aspects that are not running well (Herbert-Smith, 2017). Lecturers in this study identified two challenges during their teaching collaboration. First concern was the teaching theoretically-based topics from each course that could not be merged. As a result, lecturers determined to teach those topics solo from the second to seventh meeting.

Notwithstanding performing solo teaching in the second to seventh meeting, lecturers were constantly in contact to talk about their teaching practices and learnt from each other's expertise. In the interview, both lecturers emphasized that they learnt from each other during collaboration. L2 said that she learnt a lot about teaching methodologies and got inspired to implement them in her teaching routine. Similarly, L1 said that she learnt about educational technology from L2. Furthermore, how co-teaching enabled co-lecturers to build mutual engagement is shown on L1's statement. She said that even though they performed teaching solo in the second to seventh meeting, they still collaborated in designing assessments and exchanging teaching resources.

The fact that lecturers were learning during their co-teaching practices has exhibited one of the fundamental aspects of JPD. Reported by National College for School Leadership (2012), JPD allows collaborating individuals to learn from one another and is characterized by practice-related interaction and mutual improvement, mutually beneficial learning, and collaborative enquiry.

Additionally, lecturers evaluated their use of LMS mediating asynchronous online teaching. They realized the gap in their digital literacy. Hague and Payton (2010) described digital literacy as the ability to represent knowledge in different modes, such as visual, aural, or textual, using digital tools. To be digitally literate, one must be able to discern how and when to use digital technologies to help tasks such as generating, collaborating, and effectively communicating (Hague \& Payton, 2010). This study revealed that one lecturer showed savviness in operating Canvas and optimized its 
features to generate learning contents. Meanwhile, the other is a Canvas newbie. Consequently, a techsavvy lecturer was fully responsible to design visualization of the learning contents in the LMS they used. Meanwhile, the other contributed to review the learning contents and to give feedback to the students' posts.

\section{Further Innovation Ideas (Follow-up)}

Noticing a digital literacy gap between lecturers and a necessity to experiment with an alternative online teaching mode, lecturers devised peer technology learning and planned to have synchronous online sessions. In peer technology learning, a technologically savvy lecturer provided assistances with her cohort's LMS learning. Rather than having a fixed schedule and formal meeting for the technology learning process, they opted to have flexible interaction via chat messaging apps in a friendly atmosphere. However, they believed that if they met face-to-face, their learning would be at its best.

Synchronous online co-teaching was proposed by both L1 and L2 as a follow-up idea to overcome the issue of asynchronous online sessions. Synchronous interaction enables students and instructor to interact at the same time, typically via video conferencing tools of some kind, such as Zoom or Google Meet (Lucas, 2018). However, L2 assumed that carrying out synchronous co-teaching format would challenge them in some ways, particularly in managing lecturing and students' activity time. As a response to this, $\mathrm{L} 1$ thought that setting a clear co-teaching strategy must be done at the first hand.

The way co-lecturers figured out the issues and proposed things to tackle them is what is actually guided by JPD. In JPD, instructors should challenge their practices to figure out further innovation (Herbert-Smith, 2017).

\section{Refining Collaboration Format}

The major concern of co-lecturers in this study is to reflect on and refine the present collaborative teaching format. Their co-teaching format was dominated by team teaching strategy, as previously reported in the results of lecturers' collaborative instruction. However, next time around, they plan to implement 'one teach, one drift' strategy as part of their plan to interweave synchronous online coteaching. Both L1 and L2 agreed that this strategy and synchronous online co-teaching would be complementary, particularly in terms of time management.

From this result, this study discovered that online collaborative teaching practices encouraged co-lecturers to refine their existing co-teaching format and plan to implement different co-teaching format, that is 'one teach, one drift' strategy. In this strategy, one instructor does the teaching, meanwhile the other helps students with their task, observes behavior, or assesses students' assignments (Bacharach et al., 2008; Cook \& Friend, 1995).

\section{Students' Perception toward Online Collaborative Teaching Practice: The Strengths and Benefits \\ Bridging Student Teachers' Need of Pedagogical Knowledge and Related Educational Technology}

The findings from FGD demonstrated that TEFLTELL online co-teaching equipped student teacher with meaningful pedagogical and digital literacy. In this case, the students declared that they perceived the collaboration as a bridge to integrate the pedagogical knowledge and related technology. Through collaboration, the students view the technology as an inseparable aspect of teaching (Mahdi \& Al-Dera, 2013), especially its methods and techniques in todays' class (Ghavifekr \& Rosdy, 2015). Simply put, it has informed students' future teaching practice in a way it gave them various teaching ideas using technology. They realized that it is very important for teachers to have a full knowledge of these technologies in teaching language skills (Gilakjani \& Sabouri, 2017; Solanki \& Shyamlee1, 2012).

Accordingly, it shapes students' perspective of what millennial teacher can do to provide more dynamic and interactive class (see the following S5's excerpt).

S5: The collaboration of TEFL and TELL enables me to project what I am going to do and what I should do in my future class. TEFL gave me insights on teaching methods and techniques and TELL informed me alternative technologies to use, for example after accessing some information on cooperative approach in speaking, I accessed some information about Remo application that can be used as an alternative technology. It directly connects me to one of the techniques that I was interested in so at that time I had an idea, like 'I can use Remo application to support think pair share technique in online speaking class'. So, what benefited me is more on the implementation of teaching ideas by integrating specific teaching technique with specific technology and I am now confident that every teaching technique can be supported by suitable technology and I hope it can make difference form us as millennial teachers who are more adept to the integration of various technologies and digital applications into our teaching method to avoid monotonous learning.

The term 'future teaching' in the statement refers to the teaching practicum, or in Indonesian term known as Pengenalan Lapangan Persekolahan (PLP), and real teaching practice. In this case, S3 reemphasized, "For our PLP, we get a kind of projection of what we can do by implementing proper method with suitable technology to achieve students' learning target." Those students' 
statements reflect a more practical approach to pedagogical knowledge in the online co-teaching of TEFL-TELL course for students.

The online co-teaching also facilitated the students' quest for research in English language teaching. In this case, the co-lecturers who had different expertise were admitted as completing each other to stimulate students' by providing alternative topics related to the integration of method and technology, as revealed in the following statement:

S5: It gave me insights on method and technology exploration for my research later. So, I know it now that we can put, for example, method or technique as variable $\mathrm{x}$ and technology as variable $\mathrm{y}$. TEFL and TELL collaboration, is like, giving us the path for our research and alternatives that fit our needs.

The student's statement refers to the midterm project when the students wrote a background and literature review from the list of the alternative topics covering the integration of teaching methods and technology. It also refers to the final term project when the students had to submit a research proposal covering teaching approaches/methods/techniques with technology supports.

\section{Facilitating Learning Efficiency}

Another merit exposed to students' perception is that the collaboration facilitated their learning efficiency and practicality. As previously revealed, one of the reasons of integrating these two courses is output and topic similarity and lecturers' willingness to learn and complete each other as part of their professional development. These affected the way the weekly tasks, mid-term project and final project were designed. As an example, in the preceding term, TEFL course required students to perform teaching practice by using a well-designed method/technique as the final project. Likewise, TELL course also requested students to accomplish an instructional work involving particular technology tools. It was deemed ineffective since the two subjects' foci are in fact linked. To that end, collaboration is seen as a way the lecturers to conduct a final project merging both aspects; teaching method and technology. However, the final project was changed into research proposal project due to the pandemic situation. In this case, the students perceived this integrated task as efficient and practical (see the following S6's excerpt).

S6: It helped me in terms of practicality, for example with the similar mid-term and final project. Besides, we had a lot of subjects and assignments so with the collaboration of these two subjects with integrated output helped me in terms of task and time efficiency.

The statement further illustrates that integrated project was seen to be not only task-efficient, but also time-efficient. S1 added that the collaboration has facilitated an efficient learning since it provided comprehensive contents covering not only TEFL and TELL, but also lesson plan subject.

S1: We can know types of method and technology to use in our teaching later. So, when we had an assignment of creating lesson plan with specific learning objectives, we have those tools needed to choose appropriate method, learning activities and technology, especially applications as teaching media.

S2 likewise stated a nearly similar perspective, "... feels like three targets rather than two targets." She elaborated that TEFL explained and described various issues in foreign language teaching, while TELL fulfilled her needs for teaching media resources. She continued, "In final test of lesson plan when we had assignment to design a lesson, we are able to integrate the methods and suitable technology so it does not only gain two lessons objective but also three lessons as well." This has proven Letterman and Dugan's (2004) assumption that co-teaching enables students to access the learning contents from diverse views.

In addition, the asynchronous integrated content delivery in Canvas has granted students to learn in their own pace and be regarded efficient (Hajan \& Padagas, 2021). To this point, Canvas made the learning contents comprehensible. S2 mentioned that she and her classmates usually read, discussed the topics and searched for supported explanation from the internet.

\section{Developing Collaboration Awareness}

Apart from learning-related benefits, teaching collaboration to some extent has developed an awareness of collaboration value for the students' life. It was revealed from students' comment on whether they would collaborate in their future teaching.

S5: Yes, when I become a teacher, I will do teaching collaboration with my partner teacher, I think it's good to do, we can share information and together solve problems in the class. Besides, we can learn from each other to improve our competence as teacher.

The statement was approved by the other FGD members that collaborative teaching would give benefits in terms of personal and professional benefits (Kelly \& Cherkowski, 2015).

\section{Students' Perception toward Online Collaborative Teaching Practice: Challenges and Obstacles}

As much as online co-teaching has its merits and strengths, it also has obstacles and challenges. Due to the distinct TEFL-TELL co-teaching format in the first of the term, some students considered that the collaboration vibe was merely apparent over the 
latter half semester but less visible in the first week of the term. Also, some students lacking of reading proficiency felt overwhelmed by the amount of materials and time constraints. Moreover, the technical issues in accessing and comprehending the lesson contents have become another obstacle for less autonomous students.

\section{Issue of Collaboration Appearance}

One of the weaknesses revealed from students' FGD is the students' misperception of collaboration format. Although co-lecturers had collaborated prior to the beginning of the terms (e.g., syllabus design, topic distribution, and assessment design), they decided to put the theoretical contents in the second to the seventh meeting in the different LMS (L1 used Google Classroom and Canvas by L2). This was since co-lecturers found theoretical contents were not closely related and relatively hard to merge. The lecturers informed the students that the topics would be integrated with the already-merged project each for mid-term and final-term. However, it seemed that the message was not clearly received by the students. Some students thought that the collaboration merely started in the middle of the semester (see S6's statement):

S6: Sorry If I got it wrong, but I think this collaboration did not start from the beginning of semester. If I am not mistaken this started in the middle of semester so I think it would be better if the lecturers started the collaboration from the beginning of semester.

This misperception implies that lecturers need to state and clarify the details of learning objectives and teaching format clearly and explicitly during the first week (Letterman \& Dugan, 2004; Reed, 2012). Moreover, with the online format that limits direct interaction, some information might be perceived differently (Hajan \& Padagas, 2021), particularly by the students.

\section{Issue of Students' Learning Proficiency in Comprehending Integrated Online Contents}

Another challenge was the difficulty to comprehend the details of the content shared asynchronously via Canvas. Some students thought the texts were overloaded and they struggled to comprehend them, especially journal articles that were considered hard to comprehend. For some students with low English proficiency, it also led to learning demotivation. The difficulties are represented by the following statement:

S4: Sometimes my friends felt the materials were overloaded. They asked me, 'what the materials are about? Have you watched the video?' and many of them told me they skipped the video. Moreover, the journals were sometimes hard to comprehend so they skipped the journals and jumped to assignments to do and submit.
From the statement, it can be seen that some students sometimes skipped the opportunity to get the details. However, some other students with the same challenge found learning strategy that worked for them, S5 stated, "So many methods, approaches and techniques, I cannot remember all in details so I focused more on what I think will be suitable with my teaching later and my preferences. It is because sometimes certain methods have some similarities with other methods. And for the text, I myself knew how to deal with a lot of sources."

The student challenge in comprehending the content was also resulted from their adaptation to online learning format. S3 witnessed:

S3: This teaching collaboration was well synchronized but I felt I could not optimally comprehend all the details, maybe because I did not get used to online learning format, both through LMS or teleconference.

In this case, some students felt that lecturer's presence face to face cannot be replaced by online learning (Almanar, 2020), even with a welldesigned content and delivery. "Teaching vibe is not really felt due to less direct interaction between students and lecturers. Even though there was sometimes zoom sessions but sometimes we felt our interaction was mostly with content and text," said S1.

This challenge of comprehending online content is also related to time constraint (Karaeng \& Simanjuntak, 2021). Most students agreed that they needed more time to grasp the materials. S2 stated, "Sometimes, the time was also too short for asynchronous. Some material texts need more concentration to comprehend, by the time limitation it sometimes makes us confused. From Canvas, we can read and take note and it allows as to arrange our time to do that but sometimes my friends and me felt confused with time limitation." Accordingly, the students who took part in focus group discussion shared their expectation that lecturers should have shared the material much earlier so the students would have enough time to access the content in advance before the D-day.

Another student (S1) said that the students also needed to put the pedagogical and technology knowledge into more practices, so that it would be easier to comprehend, "So I think the lecturers can give the content of various TEFL issues and technologies earlier then ask the students to read and assign them to groups to try to implement this before and in the next meeting each group can share their experience of implementing certain technology." It implies that despite the pandemic, the students need to be assigned into the practical tasks to keep up with their needs, expectations and interests (Hismanoglu \& Hismanoglu, 2011), and also collaborative works (Osman, et al., 2010). 
Issue of Students' Learning Autonomy in Accessing Integrated Online Contents

The last finding from FGD is the issue of students' learning autonomy in accessing the LMS, learning the course contents, and finishing the tasks. As revealed by $\mathrm{S} 3$ and $\mathrm{S} 6$,

S3: The problem deals with the unfamiliarity and accessibility to canvas as LMS since sometimes the notification does not come to emails, some students had hard time to access canvas.

S6: Some of us still struggled with accessing canvas that require students to go through several stages in logging in and accessing the content. Moreover, unautomated notification to emails made some of us unaware of the new content and modules.

Those statements show that some students faced obstacles in accessing the LMS even though they were already introduced and used the LMS (Canvas) for two semesters. In this case, their technological literacy and competency (Barrot et al., 2021) hindered the students from accessing the content. Moreover, when the lecturers used Zoom that had limited duration, "the students tend to be demotivated to reenter the same link," said S6. However, another stated that the technical issue was actually not the main obstacle:

S5: And about the difficulties of canvas access, I did not think it was an obstacle because even though Canvas notification sometimes did not reach students' email, if we opened the canvas regularly, I meant based on learning schedule, we would not miss any information.

S5 highlighted that technical issue was not a significant barrier, as long as the students independently accessed it on a regular basis in accordance with the subject's schedule. In other words, she perceived that the students cannot just wait for the notifications, but actively access the learning contents.

Another finding regarding students' autonomy issue related to their efforts to learn. It is shown in the following statement:

S5: Comprehending English text is not easy for us, we need to read, translate and map the ideas and some students were not willing to take an effort of doing those steps, they rather think how difficult the assignment only by looking at the assignment and materials attachment without trying to understand what the assignment was.

This issue of some students' unwillingness to autonomously learn and wait to be spoon-fed was also related to students' motivation. Regarding this, S4 shared an idea to put a collaborative learning, "I think the students need to put in group to discuss the material because in groups we can share and in Zoom we only confirm and clarify what we have learnt." S3 and S6 also added that few students were occasionally overly reliant on their classmates by duplicating their notes, even falsifying their attendance on synchronous class. That is why they expected lecturers to apply strict netiquette such as requiring students to be on-cam during Zoom session. Those findings imply that lecturers need to encourage and facilitate students' learning autonomy (Li \& Du, 2015) as well as motivate them (Williams \& Williams, 2011). S5 stated,

S5: The students will always find the reason to challenge the task. I think the highlight on why we should learn this and that should be shared more intensively to remind us the significance of learning something.

The statement from S5 suggests the lecturers to explicitly explain the learning significance by giving helpful explanations and reasons for actions (Hawk et al., 2005) to make the learning more meaningful.

\section{CONCLUSION}

This study accentuated the empirical attempts towards lecturers' stepwise practices in carrying out online collaborative teaching and students' standpoints. This study has captured five iterative online co-teaching practices. Lecturers firstly conducted collaborative planning to prepare collaborative course syllabus and design online teaching environment. They then collaboratively taught students in online learning format, mostly in the asynchronous space via online discussion forums. During collaborative instruction, lecturers were constantly in contact to evaluate their teaching practices. They exchanged feedback to improve individual online teaching practices. Besides discovering digital literacy gap between them, they also figured out that theoretically-based topics were difficult to merge and consequently pushed them to perform solo teaching in the second to the seventh meeting. Noticing these challenges, lecturers maintained friendly communication to find out the innovation ideas. They came up with providing technology assistances by a technologically savvy lecturer and interweaving synchronous online teaching. As planned by lecturers in this study, they consider 'one teach, one drift' strategy in the synchronous online co-teaching to refine their existing team teaching format.

In response to the lecturers' online coteaching, students assumed that the lecturers' effort to teach them collaboratively has brought about merits and obstacles to their online learning experience. Lecturers' online collaborative teaching has bridged their need of pedagogical knowledge to related educational technology. It also has facilitated the efficiency of their learning. Lecturers' collaboration efforts have helped increase their awareness towards the importance of collaboration. However, students thought that lecturers should put much attention on the issue of collaboration 
appearance and students' learning proficiency as well as autonomy, particularly in accessing and comprehending integrated online contents. All in all, online collaborative teaching is worth practicing by the university instructors with a clear co-teaching format and ongoing refinements.

\section{REFERENCES}

Almanar, M. A. (2020). The shifting of face to face learning to distance learning during the pandemic Covid-19. Globish (An EnglishIndonesian journal for English, Education and Culture), 9(2). https://dx.doi.org/10.31000/globish.v7i2 76

Bacharach, N., Heck, T. W., \& Dahlberg, K. (2008). Co-Teaching In Higher Education. Journal of College Teaching \& Learning (TLC), 5(3), 916. https://doi.org/10.19030/tlc.v5i3.1298

Barrot, J. S., Llenares, I. I., del Rosario, L. S. (2021). Students' online learning challenges during the pandemic and how they cope with them: The case of the Philippines. Education and Information Technologies https://doi.org/10.1007/s10639-021-10589-X

Bhattacharya, K. (2017). Fundamentals of qualitative research: A practical guide. Taylor \& Francis. https://doi.org/10.1007/978-981-100945-7_4

Braun, V., \& Clarke, V. (2013). Successful qualitative research: A practical guide for beginners. SAGE Publications Ltd.

Cook, L., \& Friend, M. (1995). Co-teaching: Guidelines for creating. Focus on Exceptional Children, 28(3), 1-16. https://pdfs.semanticscholar.org/31ca/3592c18 acdd238ce488cd7184017b904b646.pdf

Creswell, J. W. (2003). Research design qualitative, quantitative, and mixed methods approaches. SAGE Publications, Inc.

CUREE. (2018). Improving teaching and learning through joint practice development. http://www.curee.co.uk/node/5119

Dilshad, R. M. \& Latif, M. I. (2013). Focus group interview as a tool for qualitative research: An analysis. Pakistan Journal of Social Sciences, 33(1), 191-198.

Dugan, K., \& Letterman, M. (2008). Student appraisals of collaborative teaching. College Teaching, 56(1), 11-15. https://doi.org/10.3200/CTCH.56.1.11-16

Eriksson, T., Jaskari, M.-M., \& Kinnunen, P. (2020). Co-teaching is great ! - But only if there is time: Teacher perspectives on online co-teaching. Nordic Journal of Business, 69(3), 47-69. http://njb.fi/njb-vol-69-no-3-autumn2020/

Fielder, J., \& Pearce, N. (2021, July 5). Collaboration is the Key: An EdTech Journey. https://www.bettshow.com/bett- articles/collaboration-is-the-key-an-edtechjourney

Fielding, M., Bragg, S., Craig, J., Cunningham, I., Eraut, M., Gillinson, S., Horne, M., Robinson, C., \& Thorp, J. (2005). Factors influencing the transfer of good practice. In DfES Research Report 615, Falmer, University of Sussex Fielding, $M \&$ Robinson, $C$ (Vol. 26, Issue $3 / 4)$.

Friend, M., \& Barron, T. (2021). Co-Teaching in remote and hybrid learning environmen. Marilyn Friend, Inc.

Friend, M., Cook, L., Hurley-Chamberlain, D., \& Shamberger, C. (2010). Co-teaching: An illustration of the complexity of collaboration in special education. Journal of Educational and Psychological Consultation, 20(1), 9-27. https://doi.org/10.1080/10474410903535380

Ghavifekr, S., \& Rosdy, W. A. W. (2015). Teaching and learning with technology: Effectiveness of ICT integration in schools. International Journal of Research in Education and Science, 1(2), 175-191. https://doi.org/10.21890/ijres.23596

Gilakjani, A. P., \& Sabouri, N. B. (2017). Advantages of using computer in teaching English pronunciation. International Journal of Research in English Education (IJREE), 2(3), 78-85. https://doi.org/10.18869/acadpub.ijree.2.3.78

Gillespie, D., \& Israetel, A. (2008). Benefits of CoTeaching in relation to student learning. Paper Presented at the 116th Annual Meeting of the American Psychological Association, Boston, Massachusetts, http://search.ebscohost.com/login.aspx?direct= true $\& \mathrm{db}=$ eric $\& A N=$ ED502754\&site $=$ ehost live

González, G., \& Skultety, L. (2018). Teacher Learning in a Combined Professional Development Intervention. Teaching and Teacher Education, 71, 341-354. https://doi.org/10.1016/j.tate.2018.02.003

Hadullo, K., Oboko, R., \& Omwenga, E. (2018). Factors affecting asynchronous e-learning quality in developing countries. A qualitative pre-study of JKUAT University. International Journal of Education and Development Using ICT, 14(1), 152-163.

Hague, C., \& Payton, S. (2010). Digital literacy across the curriculum: A Futurelab Handbook. Futurelab Innovation in Education

Hajan, B. H., \& Padagas, R. C. (2021). Blended learning in a research writing class: Perceptions and experiences from ESL secondary learners. TESOL International Journal, 103.

Hawk, K., Cowley, E. T, Hill, J., \& Sutherland, S. (2005). The importance of the teacher/student relationship for Maori and Pasifika students. 
Set: Research information for Teachers, 3, 4450. https://doi.org/10.18296/set.0716

Herbert-Smith, K. (2017). Joint Practice Development: the what, how and why. https://blog.irisconnect.com/us/joint-practicedevelopment-the-what-how-and-why

Hismanoglu, M., \& Hismanoglu, S. (2011). Taskbased language teaching: What every EFL teacher should do. Procedia-Social and Behavioral Sciences, 15(1), 46-52. doi:10.1016/j. sbspro.2011.03.049

Hulbert, L. A., \& McBride, R. C. (2004). Utilizing videoconferencing in library education: A team teaching approach. Journal of education for library and information science, 26-35. https://doi.org/10.2307/40323919

Karaeng, L. G., \& Simanjuntak, D. C. (2021). Exploration of EFL teachers' experience toward the implementation of E-learning amidst the Covid-19 pandemic: A qualitative interview study. Project (Professional Journal of English Education), 4(2), 324-340. https://doi.org/10.22460/project.v4i2.p324-340

Kebritchi, M., Lipschuetz, A., \& Santiague, L. (2017). Issues and challenges for teaching successful online courses in higher education. Journal of Educational Technology Systems, 46(1), 4-29. https://doi.org/10.1177/0047239516661713

Kelly, J., \& Cherkowski, S. (2015). Collaboration, collegiality, and collective reflection: a case study of professional development for teachers. Canadian Journal of Educational Administration and Policy, 169, 1-27.

Kennedy, J. V., Castro, D., \& Atkinson, R. D. (2016). Why it's time to disrupt higher education by separating learning from credentialing. Information Technology \& Innovation Foundation, 1-19. https://doi.org/10.2139/ssrn.3079817

Kluth, P., \& Straut, D. (2003). Do as we say and as we do: teaching and modeling collaborative practice in the university classroom. Journal of Teacher Education, 54(3), 228-240. https://doi.org/10.1177/0022487103054003005

Letterman, M. R., \& Dugan, K. B. (2004). Team Teaching a Cross-Disciplinary Honors Course: Preparation and Development. Source: College Teaching, 52(2), 76-79.

Li, H., \& Du, X. (2015). Teachers' perspective of their role and student autonomy in the PBL context in China. International Journal of Learning, Teaching and Educational Research, 10(2), 18-31.

http://www.ijlter.org/index.php/ijlter/article/do wnload/259/103.

Li, C. S., \& Irby, B. (2008). An overview of online education: Attractiveness, benefits, challenges, concerns and recommendations. College Student Journal, 42(2).
Lock, J., Clancy, T., Lisella, R., Rosenau, P., Ferreira, C., \& Rainsbury, J. (2017). The lived experiences of instructors co-teaching in higher education. Brock Education Journal, 26(1), 22-35. https://doi.org/10.26522/brocked.v26i1.482

Lucas, H. C. (2018). Viewpoint technology and the failure of the university. Communications of the ACM, 61(1), 38-41. https://doi.org/10.1145/3163910

Mahdi, H. S., \& Al-Dera, A. S. A. (2013). The impact of teachers' age, gender and experience on the use of information and communication technology in EFL teaching. English Language Teaching, 6(6), 57. https://doi.org/10.5539/elt.v6n6p57

Marcelo, C., \& Yot-Domínguez, C. (2019). From chalk to keyboard in higher education classrooms: Changes and coherence when integrating technological knowledge into pedagogical content knowledge. Journal of Further and Higher Education, 43(7), 975988. https://doi.org/10.1080/0309877X.2018.14295 84

Matthews, B., \& Ross, L. (2010). Research methods: A practical guide for the social sciences. Pearson Education Limited.

Mishra, L., Gupta, T., \& Shree, A. (2020). Online teaching-learning in higher education during lockdown period of COVID-19 pandemic. International Journal of Educational Research Open, l(June), 100012. https://doi.org/10.1016/j.ijedro.2020.100012

Money, A., \& Coughlan, J. (2016). Team-taught versus individually taught undergraduate education: a qualitative study of student experiences and preferences. Higher Education, 72(6), 797-811. https://link.springer.com/article/10.1007/s1073 4-015-9976-5

Morelock, J. R., Lester, M. M. G., Klopfer, M. D., Jardon, A. M., Mullins, R. D., Nicholas, E. L., \& Alfaydi, A. S. (2017). Power, perceptions, and relationships: A model of co-teaching in higher education. College Teaching, 65(4), 182-191. https://doi.org/10.1080/87567555.2017.133661 0

National College for School Leadership. (2012). Powerful professional learning: A school leader's guide to joint practice development. 1-26.

Osman, N., Nayan, S., Mansor, M., Maesin, A., \& Shafie, L. (2010). Spoken skills, communication apprehension and collaborative learning. Cross-Cultural Communication, 6(2), 117-124.

Palloff, R. M., \& Pratt, K. (2010). Collaborating online: Learning together in community (Vol. 
32). John Wiley \& Sons.

Pratt, S. M., Imbody, S. M., Wolf, L. D., \& Patterson, A. L. (2017). Co-planning in Coteaching: A Practical Solution. Intervention in School and Clinic, 52(4), 243-249. https://doi.org/10.1177/1053451216659474

Rabionet, S. E. (2011). How I learned to design and conduct semi structured interviews: An ongoing and continuous journey. The Qualitative Report, 16(2), 563-566. http://dx.doi.org/10.46743/2160$3715 / 2011.1070$

Reed, D. (2012). Clearly communicating the learning objective matters! Clearly communicating lesson objectives supports student learning and positive behavior. Middle School Journal, 43(5), 17-24.

Scribner-MacLean, M., \& Miller, H. (2011). Strategies for success for online co-teaching. Journal for Online Learning and Teaching, 7(3), 419-425. http://jolt.merlot.org/vol7no3/scribnermaclean_0911.htm

Shahabadi, M. M., \& Uplane, M. (2015). Synchronous and asynchronous e-learning styles and academic performance of e-learners. Procedia - Social and Behavioral Sciences, 176, 129-138.

https://doi.org/10.1016/j.sbspro.2015.01.453

Shapiro, E. J., \& Dempsey, C. J. (2008). Conflict resolution in team teaching: A case study in interdisciplinary teaching. College Teaching, 56(3), 157-162.

Sileo, J. M. (2011). Co-teaching: Getting to know your partner. TEACHING Exceptional Children, 43(5), 32-38. https://doi.org/10.1177/004005991104300503

Solanki, D., \& Shyamlee1, M. P. (2012). Use of technology in English language teaching and learning: An analysis. International Conference on Language, Medias and Culture IPEDR (vol. 33, pp. 150-156). Singapore, IACSIT Press.

Tannock, M. T. (2009). Tangible and intangible elements of collaborative teaching. Intervention in School and Clinic, 44(3), 173178. https://doi.org/10.1177/1053451208318682

Toquero, C. M. (2020). Challenges and opportunities for higher education amid the COVID-19 pandemic: The Philippine context. Pedagogical Research, 5(4). https://doi.org/10.29333/pr/7947

Williams, K. C., \& Williams, C. C. (2011). Five key ingredients for improving student motivation. Research in Higher Education Journal, 12, 123.

Woźniak, M. (2013). CLIL in pharmacy: A case of collaboration between content and language lecturers. Language Value, 5, 107-128. https://doi.org/10.6035/languagev.2013.5.6 